PROVIDELLO, Guilherme Gonzaga Duarte; YASUI, Silvio. A loucura em Foucault: arte e loucura, loucura e desrazão. História, Ciências, Saúde Manguinhos, Rio de Janeiro, v.20, n.4 out.-dez. 2013, p.1515-1529.

\title{
A loucura em Foucault: arte e loucura, loucura e desrazão
}

\section{Madness in Foucault: art and madness, madness and unreason}

Guilherme Gonzaga Duarte Providello

Psicólogo/Prefeitura Municipal de Ourinhos.

Rua Osório Alves da Silva, 565

19913-140 - Ourinhos - SP - Brasil

gprovidello@gmail.com

\section{Silvio Yasui}

Professor do Departamento de Psicologia Evolutiva Social e Escolar da Faculdade de Ciências e Letras/ Universidade Estadual Paulista. Av. Dom Antônio, 2100 19806-173 - Assis - SP - Brasi syasui@assis.unesp.br

Resumo

Expõe as ideias contidas em escritos de Michel Foucault, Peter Pál Pelbart e Gilles Deleuze sobre a loucura e sua interface com a arte visando explorar os questionamentos desses autores sobre a relação entre arte e loucura. Parte da ideia de que a loucura não diz a verdade da arte, e vice-versa, mas que existem conexões entre ambas que devem ser abordadas para permitir uma reflexão mais profunda sobre o tema. Problematizam-se neste texto: a afirmação de que a loucura é a ausência de obra e a interferência disso na possibilidade de uma obra artística; e a ideia da loucura como linguagem interdita, ou seja, de que a loucura não traz apenas exclusão do corpo, mas também desqualificação do discurso.

Palavras-chave: loucura; saúde mental; reforma psiquiátrica; arte.

\section{Abstract}

After presenting the ideas on madness and its interface with art as expressed in the writings of Michel Foucault, Peter Pál Pelbart, and Gilles Deleuze, the article explores how these authors question the relationship between art and madness. It begins with the notion that madness does not tell the truth about art, and vice versa, but that there are links between both that must be delved into if we are to engage in deeper reflection on the topic. The text problematizes the statement that madness is the absence of an oeuvre and examines how this impacts the possibility of achieving an artistic oeuvre. It further problematizes the idea of madness as excluded language, that is, the idea that madness implies not only the exclusion of the body but also the disqualification of discourse.

Keywords: madness; mental health; psychiatric reform; art. 
A partir das considerações sobre arte e loucura que se seguem, pretendemos apontar para uma visão mais clara das implicações das relações entre esses dois termos. Apesar de concordar com Teixeira Coelho (2002, p.161) quando diz que "percebe-se hoje nitidamente que a loucura nunca poderá enunciar a verdade da arte, assim como nunca a arte terá como enunciar a verdade da loucura", ainda acreditamos que existem aspectos da conexão entre esses dois campos que se tornam importantes como ferramentas para pensar tanto a arte quanto a loucura.

Para explorar esse tema, buscamos não só em História da loucura na Idade Clássica (Foucault, 2008), como em outros textos de Michel Foucault, apontamentos sobre tais questões. Além de examinar o que esse autor e outros comentaristas afirmam sobre o tema, seguiremos Peter Pál Pelbart em sua incursão para melhor explorar temas que primeiramente apareceram em Foucault: a desrazão e o pensamento do Fora. Essa mesma análise da desrazão e do pensamento do Fora possibilitará problematizar a proximidade entre a loucura e a arte, e a familiaridade entre ambas que hoje se vê no senso comum.

\section{Há loucura em Foucault?}

Em seu livro História da loucura na Idade Clássica, Foucault (2008) tem como objetivo estudar a estrutura da exclusão dos corpos, ou seja, ele busca entender como operam as tecnologias dessa exclusão e sua lógica interna. Para isso, propõe como tópico de estudo, como exemplo de exclusão, a loucura. Para dizer claramente, correndo o risco de ser reducionistas demais, devemos esclarecer duas coisas: primeiro, que Foucault estava estudando a loucura em busca de uma analítica da exclusão dos corpos; segundo, que seu objetivo era na verdade as tecnologias dessa exclusão que se operou sobre o louco, a lógica dessa exclusão. Como ele mesmo diz:

- Tal como Dumézil o faz para os mitos, tentei descobrir formas estruturadas de experiência cujo esquema pudesse ser encontrado, com modificações, em níveis diversos...

- E qual é essa estrutura?

- A da segregação social, a da exclusão. Na Idade Média, a exclusão atinge o leproso, o herético. A cultura clássica exclui mediante o hospital geral, a Zuchthaus, a Workhouse, todas as instituições derivadas do leprosário. Eu quis descrever a modificação de uma estrutura exclusiva. (Foucault, 2006, p.162-163)

Foucault não objetiva, em suas análises, dizer a 'verdade' da loucura, assim como não pretende falar 'pelo' louco. Então ele não fala o que é a loucura, em toda essa extensa obra? A resposta seria sim e não.

Esclarecendo: Foucault se nega a criar um novo conceito de loucura. Para ele, importa o que é entendido como "o louco", o que as diferentes sensibilidades em relação à loucura podem fazer para alterar a situação dessa exclusão. Em sua análise das tecnologias de exclusão da loucura, o pensador se concentra em uma questão muito importante: para ele, a loucura se caracteriza estritamente pela forma como a sociedade experimenta, vivencia essa relação com a loucura. Ele recusa qualquer ação do saber sobre a loucura, qualquer patologização ou conceituação, preocupando-se principalmente com a lógica da exclusão do louco, com as 
tecnologias que o retiram da sociedade. Foucault não fala o que é a loucura, entretanto, fala da loucura, pois relata o que ela é a partir dos discursos de saberes sobre esse objeto vindos de determinadas épocas (no caso, a Idade Média, o Renascimento e a Idade Clássica), de determinados momentos históricos, de um determinado saber específico, ou geral. Foucault constrói uma história do presente, mais especificamente, ele traça uma trajetória do que é conhecido hoje como doença mental e mostra como essa doença mental se diferenciou das concepções de loucura de outrora. Seu objetivo é expor as ferramentas de exclusão que se moldaram em torno do conceito de doença mental, e, para tal, usa como objeto de pesquisa a loucura e a criação do conceito de doença mental. Visa expor a história da loucura "a fim de compreender, por meio das rupturas e das continuidades, o solo que abre as condições de possibilidade da moderna ciência psiquiátrica" (Corbanezi, 2009, p.17).

Foucault (2006, p.163) busca nos mostrar o que era a loucura para a Idade Clássica não como objeto natural do saber, mas enquanto estratégia que se operava sobre os corpos: “A loucura não pode ser encontrada no estado selvagem. A loucura só existe em uma sociedade, ela não existe fora das normas da sensibilidade que a isolam e das formas de repulsa que a excluem ou capturam."

\section{Loucura: objeto historicamente constituído}

Ao longo do livro, o autor deixa claro que a loucura não é um objeto natural, existente desde a aurora dos tempos e esperando para ser entendido pelo homem, mas uma criação do próprio homem. Não se "encontrou" um portador de distúrbios mentais e se o descobriu como tal, mas se criaram a loucura e o louco. Isso se deu a partir de tecnologias dos saberes sobre esse corpo específico, a partir de múltiplas transformações no modo de se ver tal personagem, como exemplificado a seguir:

Na Idade Média, e depois no Renascimento, a loucura está presente no horizonte social como um fato estético ou cotidiano; depois, no século XVII - a partir da internação - a loucura atravessa um período de silêncio, de exclusão. Ela perdeu essa função de manifestação, de revelação que ela tinha na época de Shakespeare e de Cervantes (Foucault, 2006, p.163).

Nessa passagem, que condiz com muito do que será dito aqui, mostra-se que, ao conceito de loucura, já existente enquanto experiência sensível da humanidade, se foram subtraindo significações, numa construção daquilo que modernamente conhecemos como doença mental. Somaram-se significações também, constituíram-se continuidades e rupturas, conforme se mostra em várias partes do livro e será exemplificado adiante.

\section{Continuidades e descontinuidades na história (da experiência) da loucura}

Considerando a doença mental como criação e não objeto a priori, podemos analisar algumas passagens do texto de Foucault apenas para exemplificar esse processo de 'criação permanente', de sua construção histórica.

Segundo Foucault, os loucos, na Idade Média, pertenciam de certa forma ao horizonte social, pois havia uma experiência trágica da loucura que os conectava ao mundo como 
aqueles que dizem a verdade de forma extravagante, uma experiência que dava a eles o lugar da revelação. Isso quer dizer que a loucura tinha uma linguagem aceita socialmente, mesmo com suas particularidades. Não era ainda uma exclusão da linguagem e da sociedade, pois aos loucos cabia um discurso específico e um lugar específico (as estradas, as naus dos loucos) em relação aos outros. Mas uma modificação se processou com a Renascença:

presente na vida cotidiana da Idade Média, e familiar a seu horizonte social, o louco, na Renascença, é reconhecido de outro modo; reagrupado, de certa forma, segundo uma nova unidade específica, delimitado por uma prática sem dúvida ambígua que o isola do mundo sem lhe atribuir um estatuto exatamente médico (Foucault, 2008, p.121).

Aqui se mostra uma primeira ruptura, que marca a diferença entre o saber da Idade Média e o da Renascença acerca da loucura. Porém, a ideia de avanço, desenvolvimento histórico é estranha a Foucault, e não se pode procurar na história da loucura uma linha que leve a um ápice, ou seja, à racionalidade médica.

Ora, o que caracteriza o século XVII não é o fato de haver ele avançado, menos ou mais rapidamente, pelo caminho que conduz ao reconhecimento do louco, e com isso ao conhecimento científico que se pode ter dele; é, pelo contrário, o fato de tê-lo distinguido com menos clareza; de certo modo, o louco foi absorvido numa massa indiferenciada. Esse século misturou as linhas de um rosto que já se havia individualizado há séculos (Foucault, 2008, p.121).

Nesse momento, na Idade Clássica, internam-se devassos, portadores de doenças venéreas, libertinos, blasfemadores, suicidas etc. A loucura se perde por entre um número variado de outras experiências que têm em comum com a loucura a desrazão, o desatino.

Esse desatino se vê ligado a todo um reajustamento ético onde o que está em jogo é o sentido da sexualidade, a divisão do amor, a profanação e os limites do sagrado, da pertinência da verdade à moral. Todas essas experiências, de horizontes tão diversos, compõem em sua profundidade o gesto bastante simples do internamento (Foucault, 2008, p.106).

Pode-se dizer que a loucura, nesse curtíssimo exemplo de descontinuidade histórica, passou de um papel específico para outro papel, indistinto. Não se 'aprimorou' o conhecimento sobre a loucura em direção ao moderno saber médico, houve uma descontinuidade. Aqui se mostra que:

quis o destino, infelizmente, que as coisas fossem mais complicadas. E, de um modo geral, que a história da loucura não pudesse servir, em caso algum, como justificativa e ciência auxiliar na patologia das doenças mentais. A loucura, no devir de sua realidade histórica, torna possível, em dado momento, um conhecimento da alienação num estilo de positividade que a delimita como doença mental; mas não é este conhecimento que forma a verdade desta história, animando-a desde sua origem (Foucault, 2008, p.19).

\section{Continuando: a doença mental como invenção e não descoberta}

Isso por si só não prova que a doença mental de hoje é criação e não natural, mas demonstra o modo pelo qual ela se modifica ao longo do tempo. Considerá-la objeto criado e não natural se torna mais simples observando o que diz Paul Veyne (2008, p.266; destaque no original): 
Para Foucault, como para Duns Scot, a matéria de loucura (behaviour, microbiologia nervosa) existe realmente, mas não como loucura; só ser louco materialmente é, precisamente, não o ser ainda. É preciso que um homem seja objetivado como louco para que o referente pré-discursivo apareça, retrospectivamente, como matéria de 'loucura'; pois, por que o behaviour e as células nervosas de preferência às impressões digitais?

Exemplo insólito: se um homem, vivendo em uma ilha deserta desde sua infância, um belo dia manifestasse qualquer sintoma de psicose, tal qual uma alucinação, seria ele um louco? Talvez sim, quando piratas o encontrassem e observassem seu comportamento. Mas e se a ilha fosse o único lugar habitado na terra, e ele o único ser humano? A alucinação não seria algo tão real quanto a audição, a visão ou o olfato? Seria então ele um louco, sem outros seres para objetivá-lo como tal, rotulá-lo como tal ou mesmo vê-lo como tal? A alucinação não passaria a ser algo constitutivo da própria conceituação do que é ser humano?

Segundo exemplo insólito, agora de Veyne (2008, p.265; destaque no original): "É verbal representar-se uma loucura que 'existe materialmente' fora de uma forma que a informa como loucura; no máximo, existem moléculas nervosas dispostas de uma determinada maneira, frases ou gestos que um observador vindo de Sirius constataria serem diferentes dos outros humanos, eles próprios diferentes entre si."

Eis então a primeira consideração à qual Foucault nos leva em relação à loucura: a desnaturalização do objeto, ou seja, não o considerar como algo que porta sua própria verdade, que está e sempre esteve esperando para ser descoberta. Foucault mostra a ideia de constituição histórica desse objeto, como ele se constituiu por meio de rupturas e continuidades históricas, como ele se construiu a partir dos regimes de saber a seu respeito. A experiência da loucura é uma invenção humana. Não só na loucura Foucault considera essa desnaturalização, mas até mesmo em conceitos mais primordiais da racionalidade. Retornamos ao exemplo anterior, e, em face do que se discutiu, praticamente invalidando-o: seria aquele homem, único sobrevivente da espécie, verdadeiramente um homem?

\section{Loucura: linguagem interdita}

Há também outra consideração para se pensar a loucura, como fato social concreto: "O que é então a loucura, em sua forma mais geral, porém mais concreta, para quem recusa desde o início todas as possibilidades de ação do saber sobre ela? Nada mais, sem dúvida, do que a ausência de obra" (Foucault, 2006, p.156).

Ausência de obra? Qual seria o significado dessa afirmação? Sobre essa afirmação de Foucault cabe fazer duas considerações: uma que será explorada neste tópico e remete ao motivo de a loucura carregar consigo o crivo da ausência de obra. A outra, que será explorada alhures em face das considerações de Pelbart, identifica nessa formulação uma questão mais constitutiva da própria, e se tornará mais clara considerando as conceituações feitas pelo autor supracitado.

Para nos atermos somente à primeira consideração, pensemos que a loucura, mesmo destituída do saber atual que a coloca como doença mental, distúrbio psicológico, sofrimento psíquico (ou seja, do saber psiquiátrico), tem ainda outra significação que independe da 
ciência para sua formulação e que foi herdada da Idade Clássica: a loucura é uma codificação que leva ao silêncio.

"Que peso tem, em face de algumas palavras decisivas que tramaram o devir da razão ocidental, todas essas formulações vãs, todos esses dossiês de delírio indecifrável que o acaso das prisões e das bibliotecas lhe justapuseram? ... tudo isso não passa de tempo decaído, pobre presunção de uma passagem que o futuro recusa, alguma coisa no devir que é irreparavelmente menos que a história" (Foucault, 2006, p.156).

Sendo assim, não existiu a possibilidade de os internos dos manicômios, work houses e hospitais gerais escreverem sua própria história. Mais que isso, não houve a possibilidade de serem ouvidos ou deixarem obras para a posteridade. Como já comentamos, a loucura tinha um papel social específico e um dizer próprio na Idade Média, e essa experiência da loucura foi-se dissolvendo por entre os rostos de todos os outros sujeitos internados na Renascença, tenham sido eles devassos, vagabundos ou bruxos.

O corpo do louco é vitimado com a exclusão tal qual os leprosos e os heréticos o foram em outras épocas, mas essa não é a vitimização única que se abate sobre a loucura: Foucault demonstra com clareza que a loucura, após o Renascimento, foi capturada por um discurso amplo que a desqualificava enquanto linguagem, pois a enredava em um jogo de forças com a razão, razão essa que se tornava o ponto alto do regime de verdades ocidental. Enquanto isso, a loucura se tornava uma linguagem falsa, incapaz de falar a verdade.

A loucura tornou-se, ao longo da Idade Clássica, linguagem interdita. Entretanto, não só ela foi excluída nessa grande internação ocorrida a partir do século XVII: toda outra miríade de linguagens foi fechada pela sociedade em hospitais gerais, e todas elas acabaram por ser excluídas do domínio da verdade e ligadas à desrazão.

"A internação clássica enreda, com a loucura, a libertinagem de pensamento e de fala, a obstinação na impiedade ou na heterodoxia, a blasfêmia, a bruxaria, a alquimia - em suma, tudo o que caracteriza o mundo falado e interditado da desrazão; a loucura é a linguagem excluída" (Foucault, 2006, p.215).

No século XIX, os psiquiatras resolvem 'libertar' os loucos do convívio confinado com libertinos, hereges, usurários, homossexuais etc. para dar a eles um tratamento médico. É aqui, e somente aqui, que a loucura passa para o domínio da ciência, deixando de ser uma questão social, moral e jurídica de exclusão para ser uma questão médica de exclusão. 'Criase' a doença mental. Entretanto, a reforma de Philippe Pinel não se configurou como uma modificação dessa questão de interdição da fala: a loucura continuou silenciosa, agora sob os 'cuidados' da medicina, que exerceu um arremate dessa repressão da loucura. Apenas no século XX, com Sigmund Freud, houve, por meio da psicanálise e da psiquiatria, uma tentativa de criar uma possibilidade de entendimento da fala da loucura, por meio de construções teóricas complexas, que tentavam dar inteligibilidade a essa fala.

Passou, então, a haver a possibilidade de um diálogo entre o louco e o 'são', desde que este último seja capaz de desvendar, interpretar, por meio de uma linguagem especializada, o mistério da fala do louco. Para o homem comum, essa possibilidade de diálogo mantém-se rompida. Segundo Foucault (2006, p.215), a situação se modificou realmente, e se modificou deslocando o interdito da linguagem para uma forma ainda mais complexa. Esta última forma de interdito de linguagem seria a criação de um 'quebra-cabeças' com a linguagem da loucura: 
ela [a loucura] cessou, então, de ser falta de linguagem, blasfêmia proferida, ou significação intolerável (e, nesse sentido, a psicanálise é, de fato, o grande levantamento dos interditos, definidos pelo próprio Freud); ela apareceu como uma palavra que envolve a si própria, dizendo por baixo daquilo que diz outra coisa, da qual ela é, ao mesmo tempo, o código único possível (Foucault, 2006, p.216).

Ao longo de toda a Idade Clássica, e até mesmo no início do século XX, a loucura passa por um movimento que acaba por torná-la linguagem muda. A loucura passa a ser excluída mesmo no registro da linguagem. Enquanto várias outras linguagens que faziam parte do desatino, da desrazão e do internamento (como a libertinagem, por exemplo), começam a ser evidenciadas com o passar do tempo, principalmente pelo viés da arte, a loucura passa a ser linguagem que diz, mas não diz, que fala apenas através dela mesma - linguagem muda de verdades.

"Depois de Freud, a loucura ocidental tornou-se uma não linguagem, porque ela se tornou uma linguagem dupla (língua que não existe senão dentro dessa fala, fala que não diz senão sua língua) - quer dizer, uma matriz de linguagem que, em sentido estrito, não diz nada. Dobra do falado que é uma ausência de obra" (Foucault, 2006, p.216).

A linguagem da loucura se tornou quase um quebra-cabeça: tudo o que ela diz não passa de peças desse quebra-cabeça, cuja chave de resolução é ela mesma e que, resolvido, não diz nada além de suas próprias significações delirantes:

\begin{abstract}
no meio do mundo sereno da doença mental, o homem moderno não se comunica mais com o louco; há, de um lado, o homem de razão que delega para a loucura o médico, não autorizando, assim, relacionamento senão através da universalidade abstrata da doença; há, de outro lado, o homem de loucura que não se comunica com o outro senão pelo intermediário de uma razão igualmente abstrata, que é ordem, coação física e moral, pressão anônima do grupo, exigência de conformidade. Linguagem comum não há; ou melhor, não há mais; a constituição da loucura como doença mental, no final do século XVIII, estabelece a constatação de um diálogo rompido, dá a separação como já adquirida, e enterra no esquecimento todas essas palavras imperfeitas, sem sintaxe fixa, um tanto balbuciantes, nas quais se fazia a troca entre a loucura e a razão (Foucault, 2006, p.154).
\end{abstract}

\title{
Digressão: a experiência trágica da loucura
}

Retomemos a questão da ausência de obra, explicitada no tópico anterior, agora levando a frente seu viés de análise constitutivo. Conforme referido no segundo tópico, a análise que empreendemos visa compreender a própria constituição de tal enunciado (que a loucura é ausência de obra) e para isso segue os passos de Peter Pál Pelbart em uma conceituação que parte de Foucault, mas não segue estritamente o pensamento do acadêmico francês, abrindo novos conceitos para tornar possível a exploração do tema.

A loucura é linguagem que não diz nada. Linguagem interdita. Há, entretanto, um apontamento a se levantar, um que é mais bem enunciado na forma de uma questão, muito pertinente a esse texto: Mas não há a arte? Dentro desse domínio não existe vazão para a linguagem louca, para a loucura? Não há o caso de artistas que enlouqueceram, ou foram considerados loucos (pois, considerando nossas análises anteriores, enlouquecer e ser 
considerado louco é o mesmo)? Sade, Van Gogh, Artaud, apenas para nos ater aos mais famosos? O artista louco não produz, também, sua obra?

Anteriormente, citamos a declaração de Foucault de que a loucura, na Idade Média, cabia no horizonte social como linguagem estética, de revelação; linguagem que diz, ao contrário do que se pensa hoje, a verdade em meio a seus delírios. Segundo sua análise, existia, desde essa época, outra experiência da loucura que a ligava ao mundo por meio de um viés trágico.

Esse viés trágico foi soterrado pelo pensamento da Idade Clássica, sobreposto pela experiência crítica da loucura que culminou na doença mental. Nas palavras de Foucault (2008, p.28-29), "em suma, a consciência crítica da loucura viu-se cada vez mais posta sob uma luz mais forte enquanto penetravam progressivamente na penumbra suas figuras trágicas". E continua: “...essa experiência trágica subsiste nas noites do pensamento e dos sonhos, e aquilo que se teve no século XVI foi não uma destruição radical, mas apenas uma ocultação. A experiência trágica e cósmica da loucura viu-se mascarada pelos privilégios exclusivos de uma consciência crítica."

Essa experiência trágica da loucura era de tal forma estabelecida que a ela era permitido deixar passar a verdade através de sua linguagem. A verdade jamais é totalmente apagada do imaginário sobre a loucura, e a loucura como discurso de verdade ainda assombra o pensamento ocidental, mesmo no período em que a experiência crítica reina.

o louco, na literatura da Idade Média, do Renascimento ou da época barroca, é um personagem que conta a verdade sem saber que conta a verdade; em outros termos, é um discurso de verdade que, na realidade, não tem a vontade da verdade e não a possui nele próprio. Ora, não é este o tema que pesa tão intensamente, e há muito tempo, sobre o pensamento ocidental? Pois, no final das contas, o que Freud buscava em seus pacientes, o que era a não ser fazer aparecer a verdade através deles? (Foucault, 2006, p.241).

Entretanto, durante o período em que essa ocultação prevaleceu, essa experiência trágica da loucura é quase que estritamente do domínio da arte (vale mencionar uma exceção, Nietzsche - o filósofo que cedeu à loucura). Talvez daí venha a familiaridade que muitos ainda veem entre loucura e arte, familiaridade que liga esses dois domínios no imaginário social. De qualquer forma, as artes acabaram por levantar, por outro viés que não as técnicas psicanalíticas e psiquiátricas, o interdito sobre a linguagem da loucura.

"É justamente isso que me atrai em Hölderlin, Sade, Mallarmé ou, ainda, Raymond Roussel, Artaud: o mundo da loucura que havia sido afastado a partir do século XVII, esse mundo festivo da loucura, de repente fez irrupção na literatura" (Foucault, 2006, p.238).

Ora, não há aí uma enunciação da loucura? Por entre as obras de todos os autores aqui citados não há a loucura animando-os direta ou indiretamente? Acreditamos que essa questão será mais bem respondida mais adiante, mas por enquanto vale salientar que a loucura é de certa forma aparentada da arte, e ambas seguem sob um domínio comum que é o Fora, a desrazão, e que subentende a experiência trágica da loucura: partem da dimensão que é o não pensável, o caos, a ruína, o transgressor da racionalidade, a ininteligibilidade da natureza, o exterior ao homem... E esse domínio, ao longo do tempo, tornou-se constitutivo da loucura e da arte. A esse domínio, a partir de certo momento, não foi cedido nenhum outro meio para se fazer sentir que não a loucura, a arte e a escrita. 
Para melhor explorar a ideia do louco artista, será importante discutir outro conceito: a desrazão.

\section{Desrazão}

O Fora, a desrazão permeia o pensamento desses autores, mas a relação que eles têm com esse exterior é diferente da que os loucos mantêm. Primeiramente, vale observar que:

A esse Exterior, em outro contexto, o ensaísta francês Maurice Blanchot deu o nome de 'o Fora'. Foucault retomou esse termo e forjou a expressão de 'o Pensamento do Fora', para designar toda uma linhagem de pensadores que preservaram a muito custo - em geral às custas da própria sanidade — no seio da linguagem, da poesia, da filosofia e da arte, uma relação com esse Exterior (Pelbart, 1993, p.95; destaques no original).

Esse pensamento do Exterior, como já dito, se aparenta com a loucura, entretanto, não é em si a própria loucura. Segundo Pelbart, esse outro domínio, o da desrazão, foi soterrado na Idade Clássica por uma racionalidade crescente.

Para mais um exemplo estranho, como todas as metáforas tendem a ser, pensemos em um fazendeiro arando terra virgem: ele vai, calmamente, com a ajuda de seu animal de carga, revolvendo a terra não arada e transformando-a em terra arada. A Terra arada é útil ao fazendeiro e a toda a espécie humana, pois nela pode-se plantar. A terra não arada é o selvagem, e enquanto o fazendeiro não passar por ali, mal se pode dizer que esse lugar é de alguma forma inteligível: enquanto terra virgem é um a-histórico, um ininteligível.

Enquanto a terra arada é o domínio da razão, o domínio da utilidade e da funcionalidade, a terra não arada seria esse Fora, essa desrazão, o local que ainda não se subjugou à vontade humana. O fazendeiro seria o ser humano, e talvez se possa pensar que a besta de carga que puxa o arado seria a racionalidade, o saber humano.

Para Pelbart (1993, p.96), então:

O Pensamento do Fora é aquele que se expõe às forças do Fora, mas que mantém com ele uma relação de vaivém, de troca, de trânsito, de aventura. É o pensamento que não burocratiza o Acaso com cálculos de probabilidade, que faz da Ruína uma linha de fuga micropolítica, que transforma a Força em intensidade e que não recorta o Desconhecido com o bisturi da racionalidade explicativa. O Pensamento do Fora arrisca-se num jogo com a Desrazão do qual ele nunca sai ileso, na medida em que não saem ilesos o Ser, a Identidade, o Sujeito, a Memória, a História e nem mesmo a Obra.

É como no ditado que diz: "o louco se afoga no mar em que o poeta nada". Enquanto o pensador do Fora se relaciona com a desrazão em um vaivém, o louco é preso ao Fora, expõese totalmente e sem volta. No exemplo topográfico acima, o pensador do Fora seria alguém que vai às terras virgens em busca de inspiração, para voltar de posse de uma experiência diferenciada do que é o 'dentro'. O louco seria o menino-lobo, ou o homem exilado, forçado a viver fora da sociedade: um eremita, talvez.

Vale lembrar que, para Foucault, a loucura é historicamente constituída, e aqui se precisa salientar algo: a desrazão não é uma entidade metafísica, não é algo transcendente, mas também algo construído historicamente, ou, ao menos as formas de se relacionar com esse Fora: 
anteriormente, o Fora era o exterior ao homem, a estranheza da natureza, a transcendência do sagrado, a fúria da morte, o caos do mundo..., ou seja, tudo o que hoje remete ao ininteligível, ao irracional, à desrazão, ao caos. As formas de se relacionar com esse Fora são datadas historicamente, mas vale ressaltar que esse Fora é a própria ausência do saber, ausência de metafísica, ausência de história (ora, antes de o fazendeiro chegar às terras virgens e criar para elas uma significação, uma história, elas não possuíam história alguma, não tinham, projetado sobre si, conhecimento algum).

Quando do levante da racionalidade ocidental, da valorização da ciência, essas experiências se tornaram mudas, e esse Fora ficou limitado ao personagem excluso do louco, e, em parte, à arte, ambos sob o domínio da desrazão. O próprio nome desrazão já mostra que esse conceito se refere a uma 'não razão', significado que a liga a sua origem enquanto fora da razão, esta também historicamente datada.

Seguindo esse raciocínio, Pelbart (1993, p.97) assim conceitua a diferenciação entre o pensamento do Fora e a loucura:

seria possível pensar a loucura como exposição total e sem mediação da zona de subjetivação ao Fora. Para Deleuze, a característica maior desse Fora é a de consistir no Jogo de Forças, do Acaso e do Indeterminado, ao qual temos acesso sempre historicamente, isto é, segundo estratificações de Saber, diagramas de Poder e modalidades de subjetivação determinadas. Na loucura, o sujeito ficaria exposto sem proteção alguma à violência desse Fora, e sem condições de estabelecer com ele um vaivém ou uma relação. Abertura máxima ao Fora, e ao mesmo tempo extravio no temporal abstrato, que é sua marca.

A loucura seria então essa entrega ao Fora, em vez de uma relação de ida e volta. Aqui se encaixa a irmandade entre o louco e o artista. Nessa distinção, mostra-se a exigência que a questão 'não há artistas loucos?' impõe. Devemos diferenciar, entretanto, um artista louco de uma obra desobrada, conforme a seguir.

\section{O artista louco}

Quando indagado em uma entrevista sobre o caso dos 'gênios loucos', dos pensadores do Fora, Deleuze (2005, p.333-334) responde:

Naquilo que é chamado, grosso modo, loucura, há duas coisas: há um furo, um rasgo, como uma luz repentina, um muro que é atravessado; e há, em seguida, uma dimensão muito diferente, que poderíamos chamar de desabamento. Um furo e um desabamento. Lembro-me de uma carta de Van Gogh. "Devemos - escrevia ele - minar o muro." Salvo que romper o muro é dificílimo e se o fazemos de forma muito bruta nos machucamos, caímos desabamos. Van Gogh acrescenta ainda que "devemos atravessá-lo com uma lima, lentamente e com paciência". Temos então o furo e depois esse desabamento possível.

Enquanto uns fazem um furo no muro que separa a razão da não razão, e disso retiram inspiração para a arte (seja literatura, pintura, música, ou até mesmo a filosofia), outros fazem com que o muro seja destruído completamente e são entregues ao lado de fora. 
Vale salientar, entretanto, algumas outras questões: primeiramente, que a irmandade entre a loucura e o fazer arte, ou seja, essa empreitada rumo ao exterior da racionalidade, é ao mesmo tempo a semelhança que as aproxima e a diferença que as separa. Mais claramente, poderíamos dizer que, ao mesmo tempo em que ambos se relacionam com o Fora, com a Desrazão, a forma de cada um se relacionar é extremamente diferente.

No caso da arte, subentende-se que o artista observa o outro lado em busca de inspiração. A palavra breakthrough (traduzida como avanço, descoberta) identifica de forma acurada essa relação: uma relação de vaivém entre o Fora e a razão; na citação de Deleuze, um Fora construído cuidadosamente no muro da racionalidade. Embora haja aqueles artistas que cederam à loucura, eles passaram, segundo Deleuze, a outro momento do relacionamento com o Fora, abriram um buraco muito grande e encontraram-se com a loucura.

Na loucura, a relação é outra: é um breakdown (colapso) desse mesmo muro que o artista observa. $\mathrm{O}$ vaivém não pode ser mais empreendido no momento que a subjetividade se expõe totalmente ao Fora. Entretanto, como todos aqueles que têm contato com a saúde mental hoje em dia sabem, o 'louco' não está o tempo todo fora de si: as 'crises' e 'surtos' são os momentos em que a loucura toma conta efetivamente daquele considerado louco. É esse o movimento a que gostaríamos de chegar: não se é louco o tempo todo, quando se consideram os sintomas mais excessivos da psicose, por exemplo.

Pode-se muito bem delirar com a voz das árvores ao se passar por um bosque, mas não existem só bosques, ou seja, existem momentos de 'sanidade' em qualquer esquizofrênico. E é essa a questão que nos faz pensar sobre o portador de distúrbio mental se relacionando com a arte, pois o fazer arte, por mais que se relacione com uma dimensão desarrazoada, é um trabalho de razão. Existem relatos, por exemplo, de Van Gogh dizendo que, quando estava pintando, tinha certeza de sua sanidade, ou de Arthur Bispo do Rosário, que quando sentia 'o muro desabando' pedia que o trancassem em seu quarto com muitos materiais para que pudesse produzir (e assim evitar o surto).

É por meio desse jogo (o artista que vai e vem da desrazão, o louco que vai e vem da razão) que

Rompendo o silêncio secular a que foi condenada, a loucura encontrou nas linguagens da arte possibilidades para se expressar. Porém, o grito e a dor que com elas imprime na superfície do visível podem não ser percebidos pelo espectador enquanto tais. Introduzido nos espaços socialmente destinados aos ritos de celebração da 'arte cultural', o louco ganha uma nova sacralidade: torna-se artista e, aos olhos do espectador, gênio. Porém, se dessa maneira perde o estigma que há séculos o acompanha, sua Obra rompe com a loucura. Na moldura de uma exposição legitimada pela cultura, a expressão selvagem ganha o selo de obra de arte. E isto significa, como bem sabia Foucault, que na sociedade contemporânea o confronto entre loucura e obra é bem mais perigoso que outrora: 'o jogo delas é de vida ou de morte' (Frayze-Pereira, 1995, p.141; destaques no original).

Isso significa que, em se tratando da doença mental como fato social, tecnologia de exclusão, 'em determinado momento', ou há obra (devidamente aceita como tal, como hoje ocorre com muitos artistas loucos), ou há loucura (pois esta é indissociável, na sociedade de hoje, da exclusão que se abate sobre esse estigma). 


\section{A obra desobrada}

Para retomarmos a questão sobre a ausência de obra por outro viés, vejamos outro argumento de Pelbart (1989, p.174), além do já explicitado alhures, que questionava a ausência de obra com o artista louco:

hoje em dia basta visitar uma bienal qualquer para se certificar de que grande parte das obras parecem sugerir uma desmontagem da estrutura, da forma, da comunicação, de seu caráter de produto finalizado; atentando contra a consistência, essas obras lembram mais a ruína do que propriamente um movimento de construção ... Nada similar à noção vulgar de obra. A elas melhor se aplicaria o termo feliz de Blanchot - Desobramento. Se há ali trabalho, visa a demolição da própria noção de trabalho, de obra, de linguagem, de palavra, do enquadre, da inteligibilidade etc.

Aqui se passa o argumento: a obra, em algumas vertentes da arte atual, não se tornou também, de alguma forma, uma ausência de obra?

Continuando o raciocínio: anteriormente neste artigo, retiramos de Foucault toda uma análise do soterramento da experiência trágica da loucura. Vimos também, no segundo tópico, a exclusão da linguagem da loucura. Ambas aconteceram ao mesmo tempo, momento em que a própria invenção da loucura como a vemos hoje aparecia em forma embrionária. Atentando ao conceito da desrazão, vemos que ela se expressa quase exclusivamente por meio destas duas formas, loucura e arte.

Partamos então do primeiro argumento contra o enunciado 'loucura é ausência de obra'.

Depois de historiar o nascimento do asilo, Michel Foucault se pergunta o que sobreveio à desrazão com a medicalização da loucura operada pela nascente psiquiatria. O desatino clássico, diz ele, que era silêncio e nada diante da Razão, foi transformado no final do século XVIII, através de Goya e Sade, em grito e furor. O não ser da desrazão tornou-se com eles poder de aniquilação, violência, possibilidade de abolição do homem e do mundo. O nada e a noite da desrazão adquiriram direito de expressão 'na forma de obra', mas apenas na medida em que essas obras que o expressassem fossem mortíferas e lancinantes, capazes, na sua força, de contestarem o mundo, a razão e a dialética que as ligavam (Pelbart, 1989, p.175; destaque no original).

Ora, Pelbart parece referir-se aqui ao mesmo argumento de Foucault sobre a arte e a loucura: entretanto, Foucault se refere à loucura, enquanto Pelbart, à desrazão. Mas retomemos a questão em mãos:

Paradoxo: enquanto loucura e obra se excluem mutuamente (segundo a fórmula foucaultiana: loucura é ausência de obra), a forma maior de expressão da loucura, numa época em que ela foi sequestrada por inteiro pela 'ciência' psiquiátrica, é precisamente a obra - que ela, no entanto arruína. Por que a loucura, para expressar a ruína, precisaria justamente da obra, que é seu contrário? Por que a loucura, que implica a ausência de obra, necessita da obra para manifestar-se? Mero jogo de contrastes? (Pelbart, 1989, p.175; destaque no original).

Há então de se colocar uma questão: a experiência trágica da loucura, explorada por Foucault, seria o domínio da desrazão conforme dito por Pelbart? Nossa análise até agora nos faz acreditar que a linguagem trágica da loucura, com todos os significantes sociais que 
ela carregava (papel social possível para o louco, possibilidade de enunciação por meio da loucura), faz parte integrante do domínio da desrazão. Pelbart parte da proposição de que A história da loucura na Idade Clássica é na verdade uma arqueologia dupla: por um lado, Foucault buscou elaborar a história da loucura e, por outro, observar a desrazão. Ora, as mudanças de título do livro apontam para o mesmo sentido. Em se tratando do livro História da loucura,

o pensador da arqueologia mostrou, ao longo desse livro, como o hiato entre desrazão e loucura foi se diluindo ao longo do tempo, desaguando numa coincidência à qual ainda estamos submetidos. Se a desrazão foi 'capturada' pela loucura, não é de surpreender que a única forma de manifestação da desrazão seja a loucura, uma loucura que será, então, marcada pelo índice do grito, da vigília e da desforra (Pelbart, 1989, p.176; destaque no original).

Como já dito, à desrazão, a partir da Idade Clássica, foi permitido apenas tomar lugar na loucura e algumas vezes na arte. Mesmo a arte tem algumas poucas figuras que deram voz à desrazão, sempre num trabalho que culminou com a loucura (Nietzsche enlouqueceu, Artaud e Sade escreveram dentro dos manicômios e hospitais gerais de suas respectivas épocas). É então explicado por que a desrazão, o Fora, tem como expressão específica a loucura, sua linguagem quase que única.

Mas existe outra linguagem da desrazão: "O desobramento, já o vimos, é o que, como o neutro, anula o tempo, dissolve a história, desbarata a dialética e a verdade, abole o sujeito e faz soçobrar uma ordem. Se quisermos ver aí um 'trabalho' da desrazão, no sentido de uma demolição, nada mais justo" (Pelbart, 1989, p.177; destaque no original).

Já que a confusão entre loucura e desrazão foi instaurada, façamos como Pelbart e deturpemos a sentença de Foucault: 'desrazão, ausência de obra'. Ora, se a desrazão só pode se expressar pelo desobramento da arte, pelo grito "mortífero e lancinante" da loucura, a ausência de obra é característica da desrazão, e não da loucura, uma das únicas máscaras através da qual nossa consciência moderna ainda a vê. "Assim como em certos momentos uma sociedade pode confinar o acesso ao Fora apenas à loucura (obrigando com isso poetas, artistas e pensadores do Fora a enlouquecer), em outros momentos outros espaços podem estar abertos a uma relação com o Fora (espaços proféticos, xamânicos, místicos, políticos, poéticos, literários etc.)" (Pelbart, 1989, p.180).

\section{Considerações finais}

Vimos, então, que a loucura tem várias faces, segundo os escritos de Foucault. Apenas algumas foram salientadas aqui, para permitir uma análise mais focalizada nas questões referentes à arte. Há ainda outras questões sobre a loucura mostradas por Foucault - que não cabe levantar por sua recorrência costumeira em discussões sobre a loucura - das quais uma das mais emblemáticas é a subjugação do louco sob a forma do exílio da cidadania, apenas para dar um exemplo.

Podemos retirar algumas questões importantes a se pensar: primeiro, que pensar fora de um paradigma psiquiátrico da loucura não é só possível, como a reforma psiquiátrica vem nos dizer, mas também é um ângulo diferente para se olhar a questão, e que traz em seu 
bojo novas possibilidades para o pensar, permitindo uma análise que ultrapasse o domínio do patológico em prol de uma conceituação mais passível de interação com outros domínios da experiência humana, sendo a arte aqui nosso exemplo. Assim se torna teoricamente viável pensar que não só os chamados 'loucos' foram injustiçados por estar trancafiados em manicômios, como também que eles foram trancados por causa de uma série de modificações 'da sociedade' projetadas sobre eles, como um projetor sobre a tela do cinema, algo que cabe dar crédito apenas à sociedade (ou ao projetor).

Segundo: por meio da digressão que ocupa praticamente metade do texto, acreditamos que fomos capazes de demonstrar nosso entendimento da questão do Fora, da desrazão, e por meio dela explicitar essa outra face do estudo de Foucault em A história da loucura na Idade Clássica, deixada inconclusa e abordada por Peter Pál Pelbart. Essa explicitação serviu apenas de base para algumas outras reflexões sobre a relação da arte com a loucura que apareceram depois dessa apresentação. Entre elas: (1) a hipótese da loucura enquanto âncora racional da desrazão, que ao mesmo tempo toma dessas suas características e torna esse Fora preso ao mesmo papel social que a loucura; (2) a ideia de que a desrazão tem suas linguagens, e, apesar de essas linguagens não serem ouvidas enquanto "linguagens da verdade", elas são ouvidas, ora pela linguagem da loucura, ora pela linguagem da arte.

Essas últimas conclusões são de suma importância, pois é nesse domínio que se inscreve este artigo: a linguagem da loucura e da arte. Por meio das questões teóricas levantadas ao longo do texto, acreditamos tornar possível não só outro olhar para a loucura que foge da psicopatologia, mas também lapidar uma construção teórica que seja capaz, ainda que fugazmente, de levantar questões pertinentes ao tema proposto.

A ideia de se ouvir o discurso não científico por tempos ressoa nas ciências humanas, e essa aventura do pensamento também passa por aqui. Também passa por abrir nossos ouvidos à desrazão, seja na loucura, seja na arte, seja em domínios que ainda serão inventados. Pensemos na possibilidade, imaginada por Michel Foucault, de que, em um dia distante, o mundo sem manicômios resolva levantar a história do que foi a loucura, que há muito deixou de existir. "Entre as mãos das culturas historiadoras não restará mais nada a não ser as medidas codificadas da internação, as técnicas da medicina e, do outro lado, a inclusão repentina, irruptiva, em nossa linguagem, da fala dos excluídos" (Foucault, 2006, p.211). Não seria o aporte da loucura dentro da arte, conforme visto amplamente em trabalhos de variados Centros de Atenção Psicossocial pelo Brasil, ou mesmo a possibilidade de se elaborar uma arte desobrada, que foge da concepção de obra como a conhecemos, a possibilidade dessa irrupção da fala da loucura em nosso horizonte?

Segue-se: "Mas uma coisa permanecerá: a relação do homem com seus fantasmas, com seu impossível, com sua dor sem corpo, com sua carcaça da noite; uma vez o patológico posto fora do circuito, a sombria pertença do homem à loucura será a memória sem idade de um mal apagado em sua forma de doença, mas obstinando-se como desgraça" (Foucault, 2006, p.211).

O pensador francês acredita que, com o fim da loucura, o Fora ainda estaria lá, enquanto "sombria pertença do homem à loucura", como desgraça - da racionalidade. Finalizando, para ouvir também Pelbart, sem o qual esta análise não teria ido tão longe e com o qual concordamos teoricamente durante todo o artigo, podemos dizer sobre o agora, sobre o que o fim dos manicômios pode significar para tempos menos futuros: 
Se hoje a loucura ainda é um dos modos privilegiados de exposição ao Fora (na forma de clausura), nem de longe é o único. Por isso talvez a aura da loucura esteja cedendo lentamente, em favor da disseminação do pensamento do Fora. Se essa hipótese for correta, estaríamos assistindo não mais à liberação do louco - já em andamento - mas à da desrazão, isto é, a uma modificação profunda nas modalidades de relação com o Fora (Pelbart, 1989, p.180).

\section{REFERÊNCIAS}

COELHO, Teixeira.

A arte não revela a verdade da loucura, a loucura não detém a verdade da arte. In: Antunes, Eleonora H.; Barbosa, Lucia Helena S.; Pereira, Lygia Maria de F. (Org.). Psiquiatria, loucura e arte: fragmentos da história brasileira. São Paulo: Edusp. 2002.

CORBANEZI, Elton Rogério.

Sobre a razão do Mesmo que enuncia a não-razão do Outro: às voltas com a História da Loucura e O Alienista. 2009. Dissertação (Mestrado em Sociologia) - Instituto de Filosofia e Ciências Humanas, Universidade Estadual de Campinas, Campinas. 2009.

DELEUZE, Gilles.

A ilha deserta e outros textos. São Paulo: Iluminuras. 2005.

FRAYZE-PEREIRA, João Augusto. Olho d'água: arte e loucura em exposição. São Paulo: Escuta. 1995.
FOUCAULT, Michel.

História da loucura na Idade Clássica. São Paulo: Perspectiva. 2008.

FOUCAULT, Michel.

Loucura, literatura, sociedade. In: Motta, Manoel Barbosa (Org.). Problematização do sujeito: psicologia, psiquiatria e psicanálise. Rio de Janeiro: Forense Universitária. p.232-258. 2006.

PELBART, Peter Pál.

A nau do tempo rei: 7 ensaios sobre o Tempo da Loucura. Rio de Janeiro: Imago. 1993.

PELBART, Peter Pál.

Da clausura do fora ao fora da clausura: loucura e desrazão. São Paulo: Brasiliense. 1989.

VEYNE, Paul.

Como se escreve a história: Foucault revoluciona a história. Brasília: UnB. 2008. 